\title{
Hard Lessons for Lifelong Learners? Age and Experience in the Graduate Labour Market
}

Kate Purcell, Institute for Employment Research, University of Warwick, Nick Wilton, Employment Studies Research Unit, Bristol Business School, University of the West of England, and Peter Elias, Institute for Employment Research, University of Warwick

\begin{abstract}
The expansion of the higher education system and widening access to undergraduate study has led to growing diversity within the graduate labour supply, including increasing numbers who studied for their degrees as mature students. Analysis of graduates entering the labour market prior to the major expansion in the early 1990s indicated that those over the age of 30 had considerably more difficulty than younger graduates in accessing the career opportunities for which their education had equipped them. Is this still the case for more recent graduates? Drawing on a major qualitative and quantitative study of a class of graduates who completed their undergraduate degree courses in 1995, this paper explores early career development and employment outcomes according to age at graduation. Although we find considerable diversity among all age groups, mature graduates were more likely than their younger peers to experience difficulty in accessing appropriate employment, had a lower rate of earnings growth and expressed higher levels of dissatisfaction with their jobs.
\end{abstract}

\section{Introduction - the issues}

The graduate labour market has changed dramatically over the last two decades as a result of government policy to widen access to higher education (HE). This move from an elite to a mass system has had a fundamental impact on the labour supply and occupational structure, challenging employers' and graduates' perceptions of the relationship 


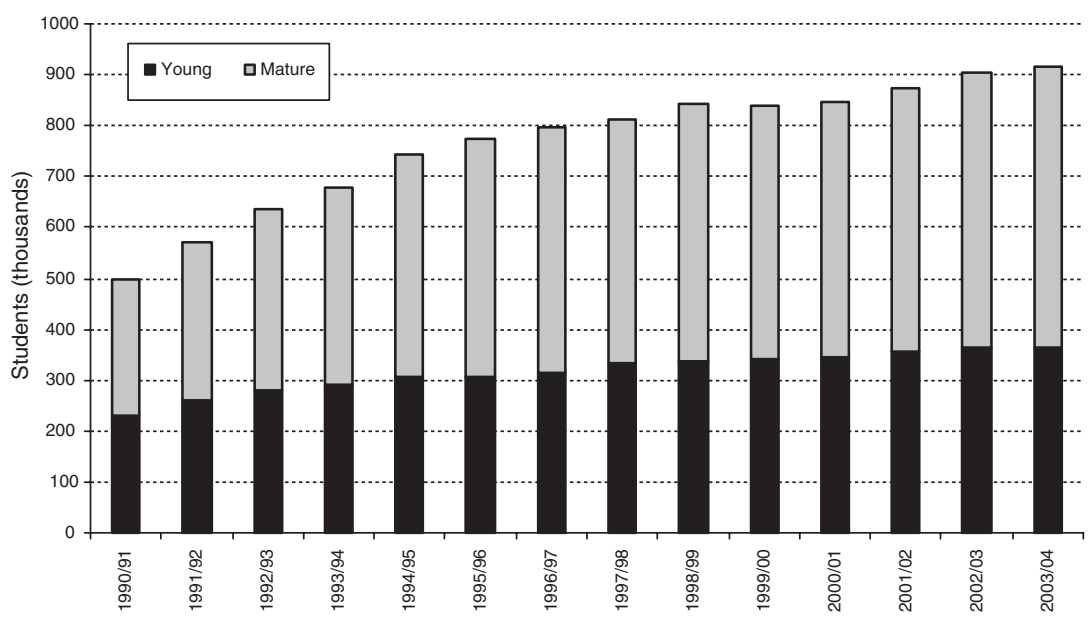

Figure 1 Home entrants to $\mathrm{HE}$ by age group, Great Britain, 1990/1991 to 2003/2004 (thousands).*

Source: Derived from Department for Education and Skills, Trends in Education and Skills figures (See www.dfes.gov.uk/trends for most recent years). Mature students are defined here as those who are over age 21 when they enter HE, corresponding to our 'young mature' and 'older mature' groups.

between $\mathrm{HE}$ and employment. This expansion of, and widening access to, undergraduate study has led to the growth of, and growing diversity within, the supply of highly qualified labour - particularly in the last decade. In addition to the increase in HE participation among school leavers and young adults, those who missed out on HE first time round have been encouraged to enter as mature students (DfES, 2003). Figure 1 shows clearly how the proportion of mature entrants to HE in Great Britain has grown since the early 1990s, at a faster rate than that of younger HE entrants. Government 'lifelong learning' policies that include further expansion of the HE system will continue to lead many higher education institutions to encourage people over the age of 30 to enrol on courses.

As the size and profile of the graduating population has changed progressively since the late 1980s and the funding of $\mathrm{HE}$ has changed in a way that requires individuals and their families to bear increasing shares of the cost of HE, questions about the value of a degree become more pertinent. Is the investment of three or more years studying for a degree a good use of time and resources for individuals, particularly those who enter HE at a later stage in their lives for whom, on the basis 
of the experiences of earlier cohorts, the returns are less certain and the opportunity costs are likely to be higher (Davies and Williams, 2001; Egerton and Parry, 2001; Jenkins et al., 2002)? Studies that predate the major expansion of $\mathrm{HE}$ in the early 1990s indicate that mature graduates are likely to have greater difficulty than their younger peers in accessing appropriate employment after completing their courses and experience lower returns, in terms of occupational and salary outcomes (Egerton and Bynner, 2000; Egerton, 2001a ${ }^{1}$; Blasko, 2002; Brennan and Shah, 2003; Egerton and Parry, 2001). The expansion of HE means that those graduating more recently have entered a significantly more competitive graduate labour market. However, ageism in recruitment and workforce age profiles are becoming more significant issues for employers because of changing legislation - although recent research on this issue among employers (Purcell, Morley and Rowley, 2002) suggested that positive discrimination to combat 'ageist' recruitment policies was seen as less of an issue in relation to graduate recruitment than in recruitment to more routine occupations.

This paper explores the similarities and differences in the early career trajectories and employment outcomes of graduates according to their age on completion of their degrees, distinguishing between younger and older 'non-standard' graduates. In the context of the changing legislative framework to tackle age discrimination in the workplace, it raises a number of issues regarding the efficacy of recruitment and selection processes, the criteria used when recruiting graduates into organisations and the obstacles faced by mature entrants to the labour market entrants.

The findings reported are drawn from a major Economic and Social Research Council (ESRC) and Higher Education Careers Services Unit (HECSU)-funded survey of graduate career paths referred to as Seven Years $\mathrm{On} .{ }^{2}$ This project had two main components: a survey of 4,500 graduates from 38 UK higher education institutions who gained their first degrees in 1995, representing the full spectrum of UK undergraduate provision and a follow-up programme of 200 detailed qualitative interviews with a subsample of respondents. The survey includes detailed work histories from the point of graduation in summer 1995 to the date of the survey (winter 2002, 2003). Responses have been weighted to be representative of all those who completed undergraduate degrees at the institutions included in the survey. A series of tests of sample representativeness has been undertaken, including attribute comparison with Higher Education Statistics Agency (HESA) population data and a telephone survey of non-respondents, all of which indicated that the educational and social characteristics of respondents are similar to those 
of the population from which they were drawn. In terms of age group, the unweighted data break down as follows: 3,405 young graduates; 385 young mature graduates; and 690 older mature graduates.

\section{Who are 'mature' graduates?}

'Mature graduates' is a complex and contested term, used differently by the various stakeholders and commentators engaged in the HE policy debate. Those who commence their studies over the age of 21 have sometimes been considered 'mature students' whereas others confine the category to those embarking on HE over the age of 25 . For the purposes of this analysis, we divide the 1995 cohort sample into three categories:

- 'young' graduates, who graduated before the age of 24 (usually embarking on HE studies at ages 18 or 19);

- 'young mature' graduates, who graduated between the ages of 24-30 (embarking on HE studies between ages 21 and 27); and

- 'older mature' graduates, who were over 30 when they completed their first degree (embarking on HE studies when aged over 28).

We made this decision on the basis of the considerations mentioned above and earlier research on employers' recruitment practices (Purcell, Morley and Rowley, 2002). Research on previous cohorts of graduates has established that those who studied as mature students had a greater propensity to have come from lower socio-economic background, to have studied at new universities or HE colleges (often within commuting distance of their homes because of other commitments) rather than older universities, and to have 'non-standard' entry qualifications (Egerton, $2001 \mathrm{~b}$; Jenkins et al., 2002). Our survey findings bear this out. Although the 'young mature' graduates were very close in social class profile to the 'young' graduates, only 40 per cent of those who graduated when they were aged 30 or over came from a professional or managerial family of origin, compared with over 60 per cent for the younger categories of graduates. Approximately 75 per cent of older and 70 per cent of young mature graduates studied at either a post-1992 university or an HE college, compared to 50 per cent of those who had embarked on courses soon after competing secondary education.

Those at the older end of the student population frequently embarked on degree courses for intrinsic reasons, to have the opportunity to study rather than as a career investment, whereas the young mature students entering $\mathrm{HE}$ after a period of employment more often took an instrumental approach, with a clear view of the opportunities to which a degree 
was assumed to lead. However, in all the graduate surveys that we have conducted over the last decade, we have found that graduates who completed their course when they were in their late 20s, 30s and 40s were most likely to have taken their courses with a clear intention of enhancing their employment opportunities. Our detailed interview data provide significant insight into the reasons why the 1995 mature graduates returned to study. For example, a 37-year-old engineer studied part-time at a 'new' (post-1992) university for his degree, as this was his fastest route to achieve chartered status, necessary for further progression. In another case, a secretary - realising that she had the ability to progress within the organisation to more interesting, responsible and well-rewarded work - took advantage of career development opportunities offered by her public sector employer to study part-time for an HNC and then an undergraduate degree. Seven years after graduation she was a highly paid 38-year-old manager, leading a team of 17 in a government agency.

In some cases, the move to university to study for a first degree had been precipitated by some unforeseen event; for example, after a previous career in the police force had been cut short by injury. However, we encountered examples of mature graduates who drifted into $\mathrm{HE}$ as a way out of frustration or dissatisfaction with their previous circumstances, without having a clear idea of the alternative career opportunities they sought. For example, a 35-year-old who had entered local government employment after ' $A$ '-levels embarked on his degree course to widen his career opportunities, perceiving his existing job prospects had 'stalled', having been prompted to 'go along with' a friend who had decided to re-enter education - and despite having achieved an accountancy post, he still appeared somewhat responsive rather than proactive in his career development.

In another case, a 44-year-old female graduate in Fine Art, working seven years after graduation as a clerical assistant in a Civil Service post for which the job requirements were three A-C grade GCSEs, had gone to university with the idea that she had always been interested in Art and felt under-educated in comparison to her children, but appeared to have lost momentum as far as her career aspirations were concerned. In both these cases, it was clear that the graduates had lacked cultural capital, mentors and well-informed advisers at both the points of course choice and transition to the labour market, thus reinforcing social disadvantage.

The factors underlying decisions to enter $\mathrm{HE}$ as a mature graduate are complex and varied and the decision to return to education was seldom one-dimensional, more often involving a combination of personal and 
career reasons. The following quote from a 39-year-old senior manager who completed a maths and computing degree in 1995 suggests that her decision to study was influenced by her changed personal circumstances, the desire to 'kick-start' her career and her initial failure to complete a degree at the 'usual' age.

I went to university doing maths originally when I was 18 and did one year and passed, but didn't like it at all. I then got married and had a child and then got divorced and suddenly thought I needed to grow up . . . and I need to support my son - and the only way I figured I could do that was to make sure I got a degree. (Senior manager, aged 39, first-class degree in Maths and IT from an HE college)

In the following sections we explore employment outcomes, examining the quality of the jobs graduates hold, their earnings, the sectors in which they work and their experiences since graduating. At times we show information for the three age groups described above. However, the greatest contrasts often lie between those who took a 'straight through' route (from secondary education to $\mathrm{HE}$ and on into the labour market) and the 'older mature' graduates who are most likely to have a significant amount of work experience before entering HE.

\section{The nature of graduate employment}

An understanding of the career paths of graduates requires a classification of the kind of work that graduates do - a classification that reflects both the demand for their graduate skills and qualifications and the extent to which these are used within their jobs. In the first phase of this research we conducted a detailed analysis of occupations and the changing distribution of graduates in the UK labour market, drawing upon information from all Labour Force Surveys conducted between 1993 and 2000. Through a careful analysis of occupational changes, using SOC90 and SOC2000, the Standard Occupational Classifications used to analyse national UK statistics since 1991, a fivefold classification of occupations was developed. Table 1 describes these categories and gives some typical examples of the kinds of jobs that fit into each. For further details of how the classification was constructed, see Elias and Purcell (2004).

Analysis of the changing composition of British employment ${ }^{3}$ over the period 1975-2000, according to this fivefold classification, shows that the occupational structure has changed in a way that has largely accommodated the increasing number of graduates (Elias and Purcell, 2004). The most substantial employment growth in recent decades have been among New Graduate occupations, jobs which have in recent years been 


\section{TABLE 1}

SOC(HE): a classification of occupations for graduate labour market analysis

\begin{tabular}{|c|c|c|}
\hline SOC $(\mathrm{HE})$ category & Description & Examples \\
\hline $\begin{array}{l}\text { Traditional graduate } \\
\text { occupations }\end{array}$ & $\begin{array}{l}\text { The established } \\
\text { professions, for which, } \\
\text { historically, the normal } \\
\text { route has been via an } \\
\text { undergraduate degree } \\
\text { programme }\end{array}$ & $\begin{array}{l}\text { Solicitors } \\
\text { Architects } \\
\text { Medical practitioners } \\
\text { HE and secondary } \\
\text { education teachers } \\
\text { Biological } \\
\text { scientists/biochemists }\end{array}$ \\
\hline $\begin{array}{l}\text { Modern graduate } \\
\text { occupations }\end{array}$ & $\begin{array}{l}\text { The newer professions, } \\
\text { particularly in } \\
\text { management, IT and } \\
\text { creative vocational areas, } \\
\text { which graduates have } \\
\text { been entering since } \\
\text { educational expansion in } \\
\text { the 1960s }\end{array}$ & $\begin{array}{l}\text { Civil engineers } \\
\text { Senior officials in local } \\
\text { government } \\
\text { Primary school teachers } \\
\text { Authors/writers/journalists } \\
\text { Social workers }\end{array}$ \\
\hline $\begin{array}{r}\text { New graduate } \\
\text { occupations }\end{array}$ & $\begin{array}{l}\text { Areas of employment, } \\
\text { many in new or } \\
\text { expanding occupations, } \\
\text { where the route into the } \\
\text { professional area has } \\
\text { recently changed such } \\
\text { that it has increasingly } \\
\text { become via an } \\
\text { undergraduate degree } \\
\text { programme }\end{array}$ & $\begin{array}{l}\text { Marketing and sales } \\
\text { managers } \\
\text { Physiotherapists, } \\
\text { occupational therapists } \\
\text { Management } \\
\text { accountants } \\
\text { Welfare, housing, } \\
\text { probation officers } \\
\text { Countryside/park } \\
\text { rangers }\end{array}$ \\
\hline $\begin{array}{l}\text { Niche graduate } \\
\text { occupations }\end{array}$ & $\begin{array}{l}\text { Occupations where the } \\
\text { majority of incumbents } \\
\text { are not graduates, but } \\
\text { within which there are } \\
\text { stable or growing } \\
\text { specialist niches which } \\
\text { require higher education } \\
\text { skills and knowledge }\end{array}$ & $\begin{array}{l}\text { Leisure and sports } \\
\text { managers } \\
\text { Personnel and industrial } \\
\text { relations officers } \\
\text { Hotel, accommodation } \\
\text { managers } \\
\text { Nurses, midwives } \\
\text { Retail managers }\end{array}$ \\
\hline
\end{tabular}

Source: Elias and Purcell (2004a).

increasingly 'colonised' by graduates and for which a degree is increasingly seen by employers as a relevant qualification for the job.

We turn now to our sample of graduates seven years after graduation to examine the types of job they have entered. Analysis of these data by age group indicates that there was little difference in the distributions of older and younger graduates seven years after gaining their first degrees. 


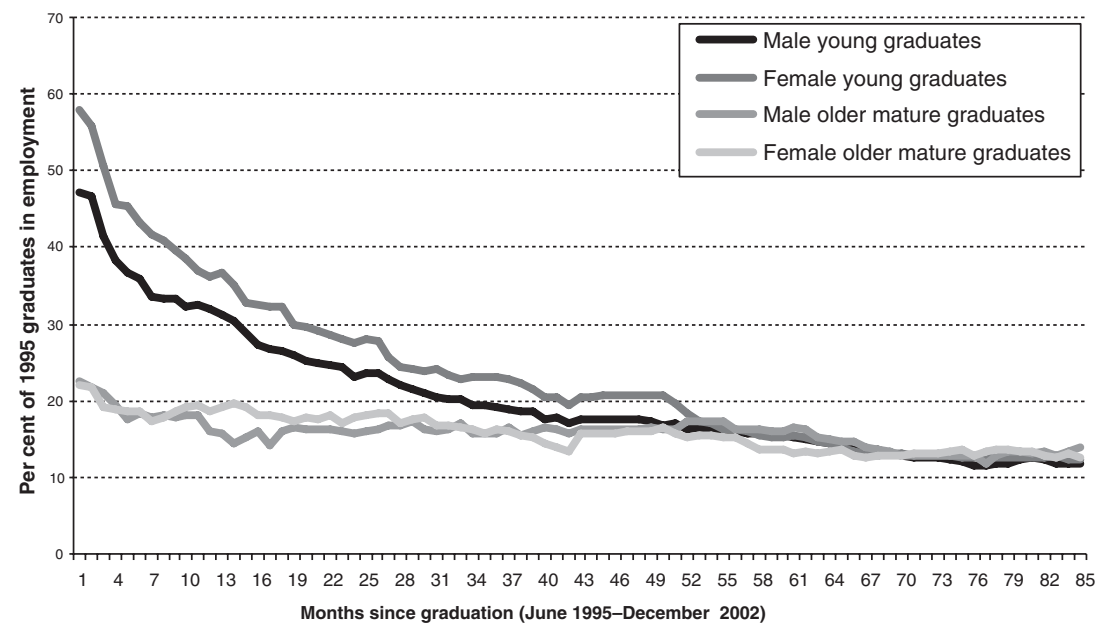

Figure 2 Movement out of non-graduate jobs (SOCHE) by age at graduation and gender (shown as a proportion of all 1995 graduates in employment).

Both older and younger mature graduates were slightly more likely to be in non-graduate jobs than the young graduates, and the oldest group are somewhat more likely than either of the others to be in niche graduate jobs, and slightly less likely to be in traditional or new graduate occupations. Given that the survey data are longitudinal, ${ }^{4}$ we are able to show the evolution of these graduate career paths. How have graduates moved into and within the labour market over this seven-year period? Comparing the movement of older mature and young graduates out of the non-graduate category of jobs, Figure 2 shows that mature graduates were substantially less likely to enter non-graduate employment as a short-term expedient - but those who did so may have found greater difficulty in moving out of them into more appropriate employment.

We turn now to an examination of the characteristics of jobs held by these graduates. We had included, in both the original 1998/1999 survey and the 2002/2003 follow-up, a question which asked the respondent to state whether or not the job they held at the time of each survey offered any of the following features:

- Competitive salary?

- Continual skills development?

- Interesting and challenging work?

- Socially useful work?

- Long term security? 


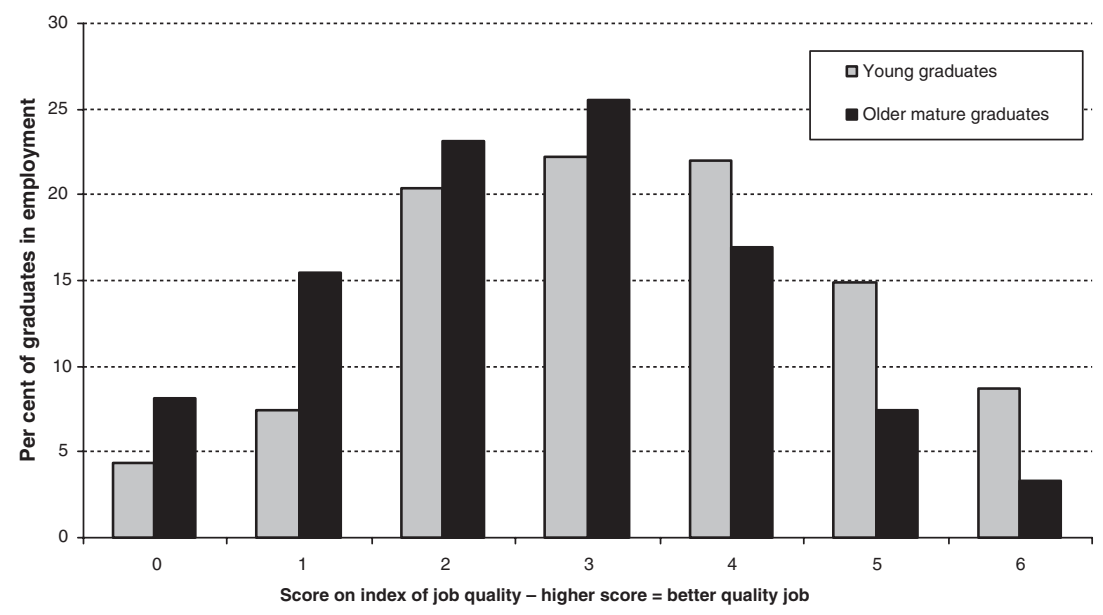

Figure 3 Distribution of scores on the index of job quality for job held at the time of the survey (2002/2003), comparing young graduates and older mature graduates.

- Opportunities for an international career?

- Opportunities to reach managerial levels?

- Progressive and dynamic organisation?

- Working with people you enjoy socialising with?

From this set of questions, responses to the six items highlighted have been found to be useful indicators of the 'quality' of jobs across the occupational spectrum, correlated with both earnings and more subjective evaluations of job satisfaction of different graduate cohorts at different stages of their careers (Elias et al., 1999; Purcell et al., 2005). A scale was constructed by simply awarding one point when the respondent indicated that their job offered any one of the six items. This yielded a 'quality index' for the job with a minimum value of zero and a maximum value of six. While average scores had increased in the four years between the two surveys for both, young graduates had higher scores than their older peers at both points. The average value of the index for all employed 'young' respondents in 2002/2003 was 3.3, compared to 2.6 for 'older mature' graduates. Figure 3 compares the distributions of scores on this index of job quality for young and older mature graduates, for the jobs held by respondents in 2002/2003. For the older mature graduates, the distribution of quality index scores seven years after graduation was more skewed towards the lower end of the scale than for the young graduates. 


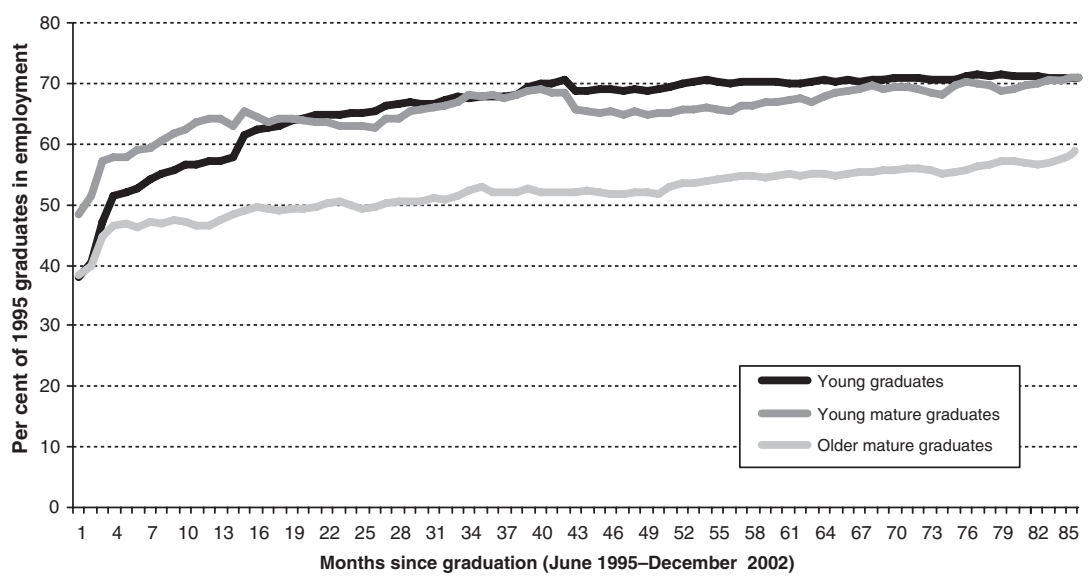

Figure 4 Percentage of employed graduates stating that a degree had been required for their job, by age at graduation.

One of the most powerful analytic devices in the survey was the collection of detailed activity histories, where respondents were asked to complete a comprehensive account of every job, period of full-time study or gap in their labour market participation for other reasons. For every job, they were asked to indicate whether or not their degree was required, whether or not they were using the knowledge acquired on their course and whether or not they were using the skills developed as undergraduates. Analysis of the patterns of these responses for the three age groups reveals interesting differences. Figure 4 shows that just under half of the young mature graduates in employment in each month after graduation had entered jobs for which a degree had been required immediately after completing their courses and the proportion had rapidly risen to 60 per cent, growing to 70 per cent by the time of the $2002 / 2003$ survey. The youngest graduates took longer to enter these jobs, probably because they were more likely to take a gap year or to study full-time for a further year before embarking on their careers. The profile for the older graduates, however, is different - parallel but lower, growing slowly from approximately 50 per cent six months after graduation to just under 60 per cent in $2002 / 2003$, seven years after graduation.

Figure 5 focuses on the comparison between the older and younger groups, comparing men and women - and provides a snapshot illustrating the greater propensity of older males to be in non-graduate employ- 


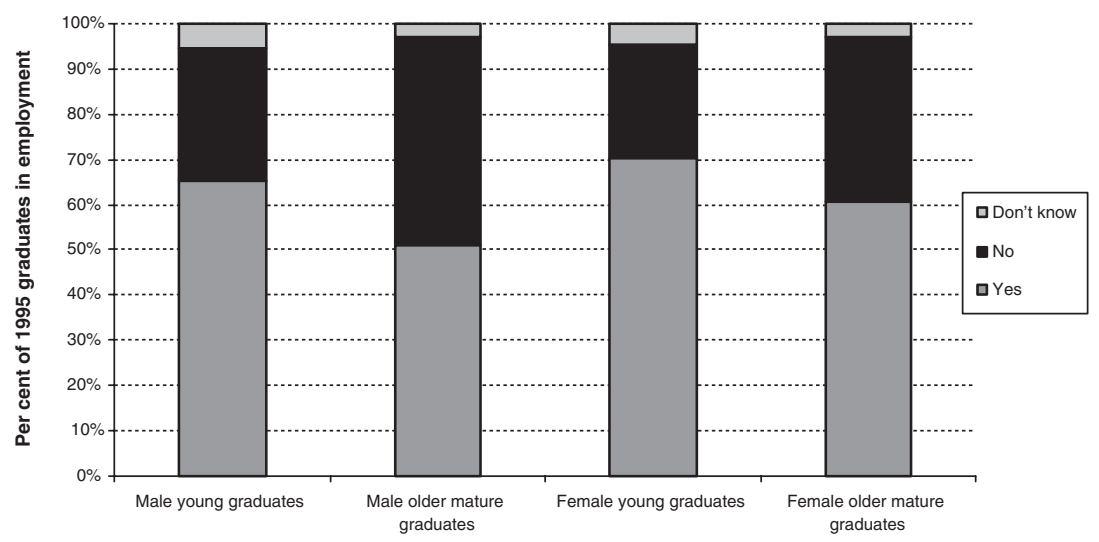

Figure 5 Percentage of employed graduates who stated that a degree was required for their current job (2002/2003), by age group and gender.

ment at the 2002/2003 point of survey. Both young and older women, it seems, were more likely to have been in jobs at the time of this survey which required them to have degrees, supporting the finding (Halford, Savage and Witz, 1997) that credentials are more important for women in enabling them to access career opportunities - or perhaps that women are more likely to enter occupations where credentials are unequivocally prerequisite: for example, teaching rather than management.

Figure 6 shows that older mature graduates were significantly more likely to have entered a job where they were required to use the knowledge acquired on their 1995 degree programme soon after graduating: after two to three months, around three quarters were in such a job. The young mature graduates took around a year to reach the same level and thereafter, the trends for the two mature groups are indistinguishable. By comparison, the young graduates were very much less likely to enter such a job soon after graduation or to be in it seven years later - although over two-thirds had done so by the survey point. Thus, although the majority of graduates had been required to draw on their subject knowledge for most of their careers since graduating, the fit between knowledge gained and required appears to have been closer for the older graduates. It is interesting that, particularly among the older mature graduates, a higher proportion claimed to be using their subject knowledge than had been required to have a degree - which could imply lack of recognition of their expertise on the part of employers rather than lack of use of it. Figure 5 also shows how the graduates reported using the skills deve- 


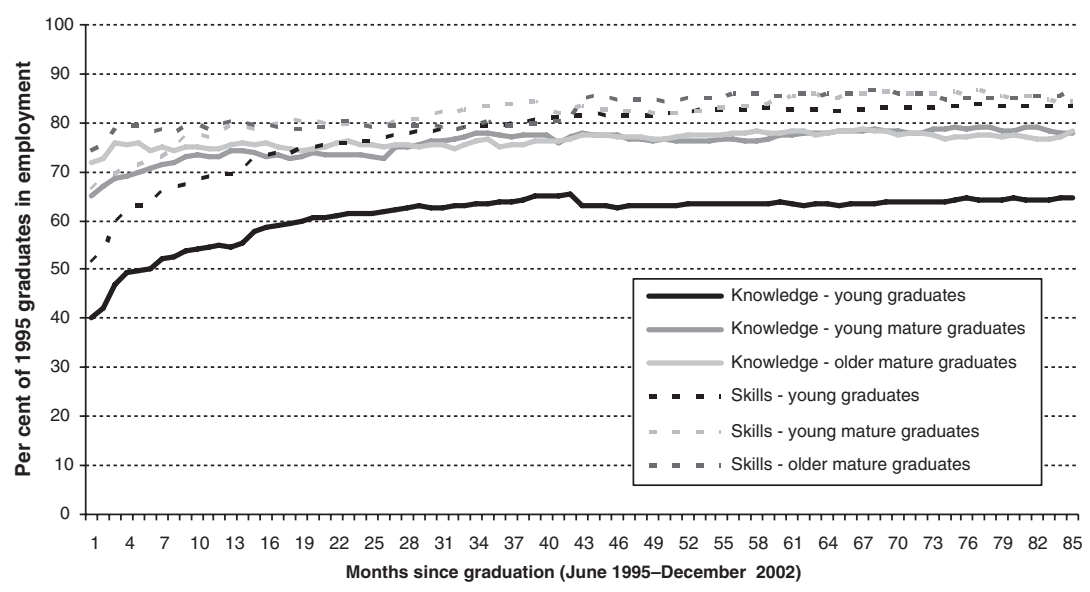

Figure 6 Percentage of employed graduates stating that they were using the knowledge and skills acquired on their 1995 degree course, by age at graduation.

loped on undergraduate programmes more than their specific subject/ discipline knowledge, with very little difference in the subgroups, apart from the different entry trajectories established by analysis of earlier variables. Approximately two and a half years after graduation, the experiences reported by the three groups converge.

\section{The earnings of mature graduates}

Earlier work (Egerton, 2000; Egerton and Parry, 2001) has established that mature graduates acquire a lower graduate premium (the pay difference associated with graduation from HE). This lower premium is attributed to a number of factors, including the different social background of mature graduates, the types of higher institution they are more likely to attend, and the tendency for older mature graduates to work in the public sector (Rees and Shah, 1995). We have shown in our earlier work (Elias and Purcell, 2004) that the graduate premium develops over a 10-15-year period after graduation. Do mature graduates experience a lower rate of growth of earnings after graduation than young graduates and, if so, is this attributable to their differing social backgrounds, lower levels of school-based qualification and the types of occupation in which they work? In this section we explore these issues in some detail, making use of the survey information from which we have computed the annual rate of growth of real earnings in the period from their first main job after graduation to the time of the survey in $2002 / 2003$. 


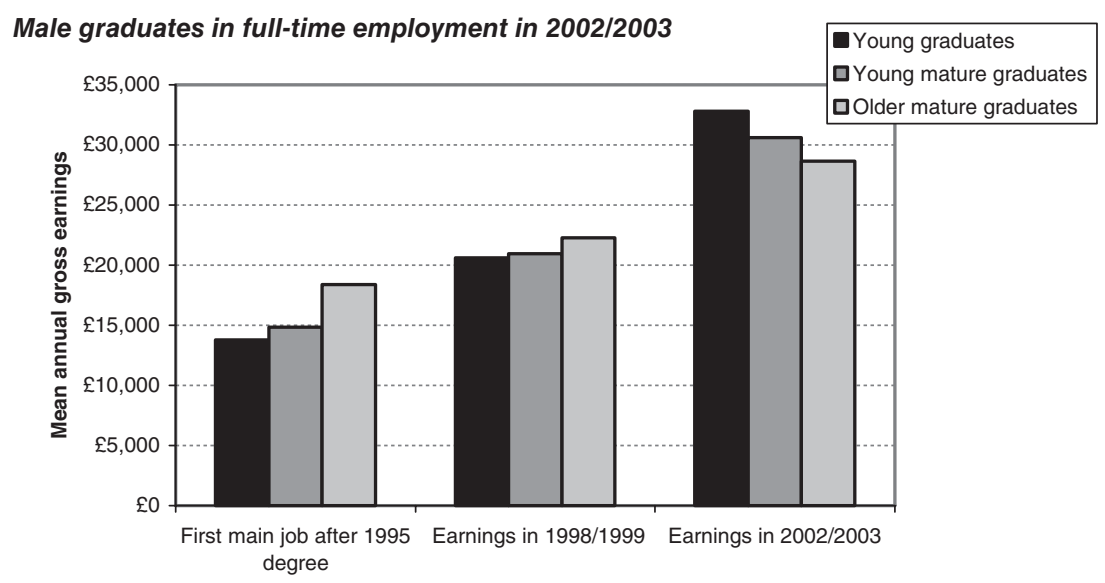

Female graduates in full-time employment in 2002/2003

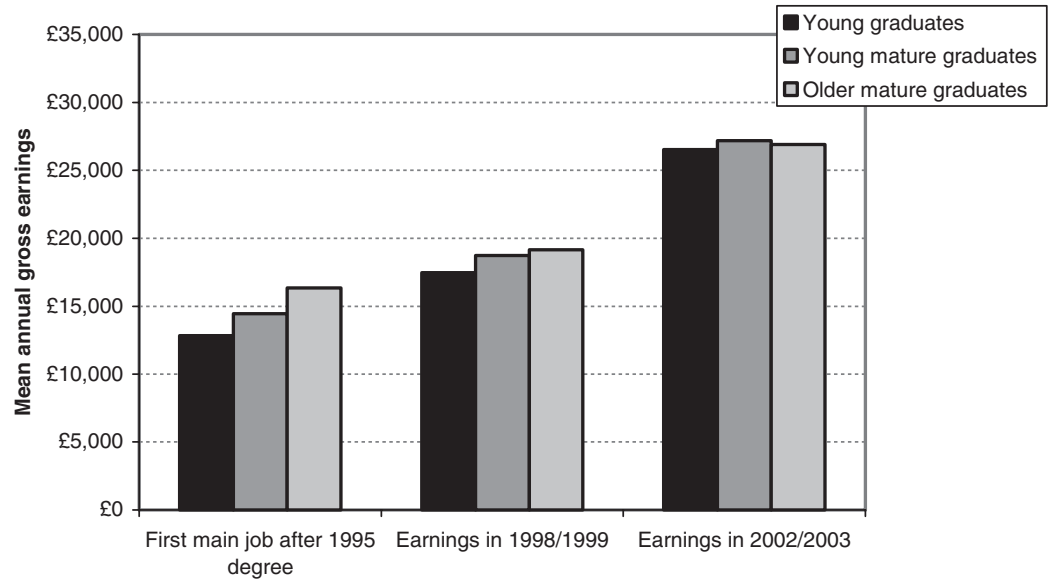

Figure 7 Growth of earnings between graduation and 2002/2003, by age at graduation.

Figure 7 shows that the contrast in growth rates between young graduates and older mature graduates is greater for men than it is for women. While the earlier work experience of older mature male graduates gives them a commanding salary lead over younger graduates in their first main job after graduation, this situation is reversed seven and a half years later. For female graduates, the generally lower rates of growth of their (lower) earnings relative to males', particularly over the 


\section{TABLE 2}

Main influences on the annual rate of growth of real earnings of graduates, 1995-2002/2003

\begin{tabular}{ll}
\hline $\begin{array}{l}\text { Factors associated with a slower than } \\
\text { average rate of growth of earnings }\end{array}$ & $\begin{array}{l}\text { Factors associated with higher than } \\
\text { average rate of growth of earnings }\end{array}$ \\
$\begin{array}{l}\text { Arts degree, education degree, other } \\
\text { vocational degree and social science } \\
\text { degree }\end{array}$ & $\begin{array}{l}\text { Maths and computing degrees, } \\
\text { business studies and law }\end{array}$ \\
$\begin{array}{l}\text { Studying at an HE College } \\
\begin{array}{l}\text { Low 'A'-levels, access qualifications } \\
\text { only or HNC/HND }\end{array}\end{array}$ & $\begin{array}{l}\text { Studying at a 1992 university } \\
\text { High 'A'-levels }\end{array}$ \\
$\begin{array}{l}\text { Berking in a non-graduate job } \\
\text { Being a woman an older mature graduate }\end{array}$ & $\begin{array}{l}\text { Working in a modern graduate job } \\
\text { Being a man } \\
\text { Being a young graduate }\end{array}$ \\
\hline
\end{tabular}

last three years, show a similar convergence among age groups, but not the dramatic reversal displayed by the male subsample.

To investigate these trends in more detail, we regressed the annual rate of growth of earnings on a variety of factors: subject area of study, entry qualifications, class of degree, type of higher education institution attended, social class background, occupation, age and sex. Full results are displayed in the appendix to this paper. In Table 2 we attempt to summarise the main influences that are detected.

None of these results is particularly surprising, but what is remarkable is the sheer scale of the graduate earnings growth premium associated with youth. From the more detailed results shown in the appendix to this paper, it can be seen that, ceteris paribus, those who graduated at age 22 saw real earnings grow about 6 percentage points per year faster than for those who gained a degree at age 32 years. ${ }^{5}$ This result is obtained after taking account of the different social backgrounds of mature graduates, their entry qualifications and the subjects they studied.

\section{Where do graduates work and what do they do?}

Comparison of the sectoral employment locations of younger and older graduates is interesting. Where are they located in the workforce, and what are their jobs? Our data reinforce the well-established finding that mature graduates are significantly more likely than younger ones to work in the public sector and more likely to be self-employed (Elias et al., 1999; Egerton, 2000). Two-thirds of older mature graduates were employed in the public sector compared to one-third of young graduates 
and 45 per cent of the intermediate group. This may reflect differing choices or restricted opportunities. Are there 'young industries' where well-qualified but older applicants have particular difficulty in accessing opportunities? In a recent study of employers (Purcell, Morley and Rowley, $2002 \mathrm{op}$. cit.) most of the large private sector organisations studied - and even public sector organisations whose priority was to attract 'Fast Track' graduates - operated graduate recruitment programmes that were designed for graduates with little or no work experience. For example, major retailers and international accountancy firms said their organisations would 'divert' experienced mature graduates away from their graduate trainee schemes. In contrast, several public sector employers of graduates had flexible graduate trainee programmes that accommodated prior experience and allowed relevantly qualified graduates to join at different stages or 'fast track' through elements of the scheme, which made them more accessible to older graduates.

Different propensities to work in the public and private sectors of older and younger 1995 graduates were evident, with the older group substantially more likely to be employed in education or other public services and less likely to work in all the other sectors except construction and transport - both sectors with public as well as private employment opportunities. Many of the younger graduates we have interviewed commented that one of the things they liked about their work was that it was in 'a young industry'. Investigation of the sectoral distribution of 1995 graduates in 2002/2003 showed a higher concentration of young graduates working in Information and Communication Technology (ICT) and business services. Older mature graduates were less than half as likely as young graduates to have been working in business services, banking, finance and insurance, or in ICT. The following interview extract is one young mature graduate's account of applying to graduate training schemes in the hospitality industry:

I wanted to go more into management training but a lot of the hotel management schemes had an age limit on them and, at the time I graduated, I was too old [for] a lot of the big hotel chains ... I did try to get on them but I didn't get anywhere ... Presumably they wanted young people to work themselves up ...

Interviewer: Did you consider [age] to be a problem at all, in those seven or eight months when you were applying for all these jobs?

Possibly. Definitely [for] the graduate training schemes they want the young go-getters. I don't know why I applied and I know I had no chance, looking back it was ridiculous. (Funding Advisor, age 33, with a 2:1 degree in Business Studies from post-1992 university) 
In occupational terms, the differences among the three groups were less dramatic, and reflected the sectoral distribution and the gender differences in the composition of the age subsamples. Older graduates were somewhat more likely to be professionals and less likely to be managers and administrators, reflecting their concentration in the public sector and in the education sector in particular. Younger mature graduates, more often males than females, were likely to be in associate professional occupations.

One of the most interesting differences between the three groups was the different number of 'events' recorded by them on the work history schedules. Respondents were required to list all events, whether job, education or training course, self-employment, unemployment or nonemployment. Age was clearly correlated with propensity to have had activity changes - although it was complicated, with different patterns of job tenure. New graduates have been found in the past to be highly mobile and exhibit relatively high job turnover (Elias and Rigg, 1990). Seven years on, it is clear that this propensity to move jobs frequently is related to age and, possibly, lack of personal commitments to others. Older graduates were less likely to have reported multiple activity changes since graduation. While 25 per cent of the youngest group had remained in the same activity since January 1999, over a third of the young mature graduates had done so and almost half the older graduates had only had one event - normally, one employer or job. Further investigation is required, but it seems that maturity leads to greater stability which could reflect greater risk-aversion or inertia, or more effective career planning and targeting of appropriate jobs.

It appeared from some of the responses to attitudinal questions in the survey that relative maturity was associated with different values and priorities, in relation to careers and wider social integration. Respondents were asked to indicate the importance to them of a number of long-term values ranging from high financial reward to concern with involvement in local community issues. Older mature graduates were significantly more likely to have highlighted the importance to them of doing socially useful work (perhaps not surprising given their great propensity to work in the public sector), and were less likely to give priority to high financial reward or, interestingly, to consider career development as 'very important'. These age differences in orientation to work were also revealed by answers to the question about the factors that had been important in their decision to take their current job. Comparison between older mature graduates and their 'traditional' counterparts indicated that young graduates were significantly more likely to highlight 


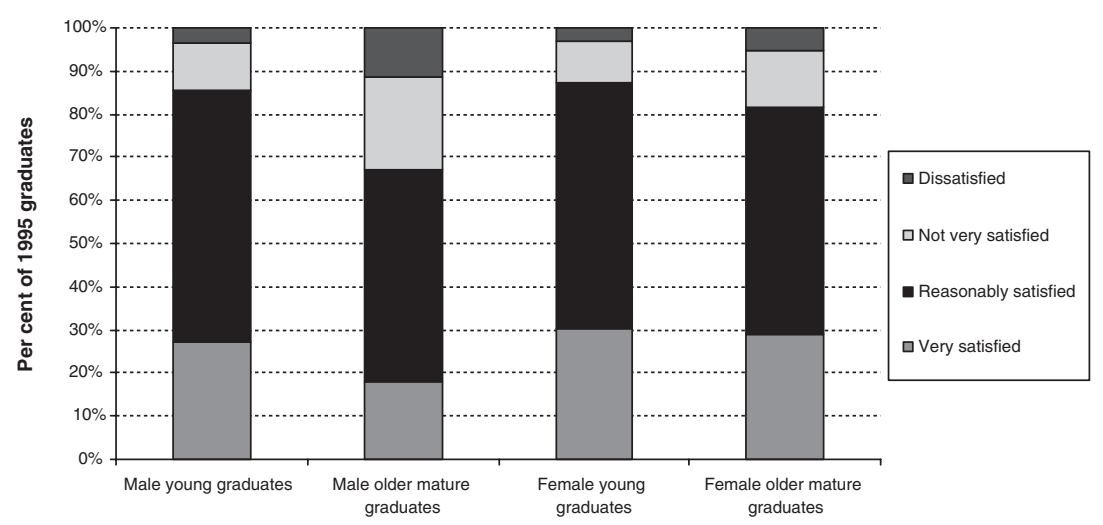

Figure 8 Level of satisfaction with career, by age group and gender.

the importance of an attractive salary (45 per cent) compared to older mature graduates (30 per cent). Similarly, opportunities for career development were also found to have been more important among the younger group, with 58 per cent reporting that this played a part in their decision compared to 38 per cent of mature graduates.

As with the other age categories, the majority of mature graduates were satisfied or reasonably satisfied with their careers to date when surveyed in 2002/2003, as Figure 8 shows. However, comparison of the oldest and youngest groups, disaggregating by gender, reveals that older male graduates were notably less satisfied with their career to date than older female graduates.

\section{The experiences of mature graduates}

Levels of satisfaction in careers, opportunities and prospects are dependent upon expectations and, consequently, perceived labour market success among any group of graduates is influenced by the differing aspirations and hopes they had at the end of their courses, and the extent to which these have been realised. The interview data suggest differing sets of assumptions made by mature graduates about the likelihood of labour market 'success' and the speed at which this can be achieved. The majority of the mature graduates interviewed had left HE expecting that they would be able to find employment that was commensurate with their qualifications and skills, and that their greater maturity and commitment would be regarded positively by employers. However, it appears 
that many subsequently had to reassess this in the light of experience. The following extract highlights a recurrent theme in the interviews:

I thought that employers would look at me and think, 'as old as he is ... he's been made redundant, he's got a degree, it shows drive and enthusiasm to get on and do things'. But it didn't work out that way: it took about four years before I got a job that I thought I should have been able to achieve two or three years beforehand. So I was almost getting disheartened . . . It was rather a naïve idea that I would leave university [thinking that] there would be would be jobs and opportunities out there. I didn't expect it to be quite as difficult as it was to get this kind of job ... (Transport Planner age 48, graduated with a 2:1 in Rural Resources Development from a new university)

Among the interviewees, differences were certainly evident in the manner in which mature graduates pursued labour market success. One of the most successful, in career terms, was Mary, a 39-year-old senior manager working in a large global consultancy firm who was able to achieve initial and subsequently rapid corporate success by offering to work unpaid for a large accountancy firm to gain relevant experience, which had led to an offer of employment. She was able to do this despite being a single mother, because her own mother was able to care for the child while she worked, and she had family financial support. In this case, it is pertinent that initial recruitment into the organisation was achieved by adopting an approach more often used by younger peers, via unpaid work experience that provided the opportunity to prove themselves prior to application for 'fast track' employment; a strategy that is unlikely to be an option for most mature graduates. Once into the organisation, Mary's progress has been rapid and it is noteworthy that part of her subsequent advancement has been a willingness to be mobile and to work away from home for relatively long periods, supported throughout by her family. In effect, although she is a mature graduate and a parent, she has been able to take advantage of career opportunities and satisfy the demands of the job by being able and willing to act like the traditional young graduate recruit, unimpeded by commitments to others. In contrast to this rather exceptional case, 'success' for mature graduates appears more likely to be achieved incrementally. For example, the 46-year-old local authority transport planner cited previously took five years to find a job in his locality that made use of his degree knowledge, filling a range of distinctly non-graduate roles, some in related areas, before finally achieving his objective.

In terms of labour market outcomes and, specifically, obtaining entry into jobs and organisations, the interview accounts suggested that mature graduates often believed that they had encountered obstacles 
related to the fact that they were older than the stereotypical new graduate. Older graduates often offer employers exactly what they claim to seek: work experience, maturity, a strong work ethic and evidence of transferable skills such as time management, flexibility, adaptability, stability and commitment. Their accounts indicated that they had had to be more persistent and more proactive in persuading employers to consider them. Barbara's account is typical:

I applied for about 40 jobs when I left, after getting my occupational psychology Masters ... Out of 40 applications I got three offers of interviews ... I think once I stopped putting my age on my CV I got more interviews. I'd also make it less obvious on the CV that you are that age by not giving so much information about your early career.... I spoke to a number of recruitment people while I was doing my temping and they do recommend that you don't put your age, you don't put your marital status . . . you try and block out, try and prevent or anticipate as many HR biases as you can'. (Senior Project Co-ordinator aged 39, 2:1 in Psychology from an old university)

Several other interviewees similarly felt that age had probably been used as a means by which employers had rejected applications for employment. Moira had clearly had her confidence seriously eroded by lack of success in job applications in her attempts to move on to a more demanding job. She reflected:

I'm 47 in March and certainly three years ago I seemed to be getting many more interviews per application than I am now . . . it might not be age but I don't know ... you always think it's you, don't you? (Education Development Officer age 46, 2:1 degree in Human Sciences from an old university)

One of the recurrent themes of the interview programme was that mature graduates often find that they are caught in a 'Catch 22' situation because they have maturity and experience but it is assumed that these render them inappropriate for 'new graduate' jobs. In several interviews it was suggested that the most significant barrier to initial, and subsequent, recruitment was that often employers make assumptions about the type of employment suitable for and the degree of experience expected of a person of 'a certain age'. It was felt that often employers were reluctant to offer initial graduate level employment to mature graduates but at the same time assume or expect a certain degree of experience even if in relatively specialist areas.

I think perhaps the age worked against me on two grounds. One was that I was too old for real basic, bog-standard graduate entry [and] I didn't have the experience to go with the age [for] other jobs. (Transport Planner age 48, with a 2:1 in Rural Resource Development from a new university) 
This was echoed time and time again in the interviews with mature graduates. The lower propensity to be short-listed or recruited was clearly most pronounced in what Malcolm described as 'young' industries: in his case, the music industry. Despite a degree in music and his recent experience and developing expertise within the industry, he felt his opportunities for progression outside his current organisation were extremely limited by his age. He said:

It's a very young industry and I'm getting to an age where it's difficult to get jobs anyway. There is an ageism about jobs, I think. [It's] very hard to get into because they all want experience already and if you go for the lesser trainee they want someone younger and that's a real problem ... (Data Communications Administrator, age 43, 2:1 in Music from a new university)

Furthermore, Barbara had found that sometimes her age had led to unreasonable expectations on the part of employers, so that she was subjected to more difficult selection procedures than those used to assess younger recent graduates:

I went for a really horrible interview and I turned up and they then asked me to give a training seminar using a particular tool that I'd come across for the first time during [my] Masters course in occupational psychology. They expected me to be able to do a consultancy thing using this tool... They said, 'Well, if you'd been a new graduate we wouldn't have asked you to do that! Normally, we would give that task to someone who'd done two or three years of consultancy work'. That's the kind of attitude that you come up against, people assume that you've got this knowledge, experience just because you happen to be a bit older when, in fact, you're at the same [career] developmental stage [as younger graduates]. (Senior Project Co-ordinator, age 39, 2:1 in Psychology from an old university)

While the interviews suggest that mature graduates of all ages were mainly positive about their undergraduate experiences and outcomes, lack of initial success in the labour market, often continuing for a significant period after graduation, led to disillusionment among some mature graduates about their investment in HE. Several respondents expressed disappointment that there appeared, contrary to assumptions, little advantage in the labour market as a result of having attained a degree. Robert said:

I think perhaps people didn't understand - 'Why has he gone to work for six years and gone to college and not done it the other way around?' - and yes; I was 28 with a 2.2.degree and I wasn't a 23 year old with a $2.1 \ldots$ and possibly because somebody looking at my $\mathrm{CV}$ would think 'That person doesn't have any direction, doesn't really know what they want to do'. (Accounts Administrator, age 35, 2.2 in Business Studies from new university) 
Robert's case highlights three issues raised by others: employers' uncertainties about where mature graduates might fit into organisational hierarchies where they might be somewhat anomalous - for example, reporting to line managers younger than themselves; employers' prejudices in imputing character flaws in those who had not followed the 'normal' (in fact, middle class) educational route from secondary school into HE; and the fact that mature graduates themselves appear likely to have lacked guidance in choice of course and career direction and be somewhat naïve about the opportunities which await those with degrees.

While mature graduates are clearly not a homogeneous group, the interview data revealed common themes, suggesting that mature graduates tend to be faced with greater obstacles to appropriate labour market integration and achievement of their aspirations than the younger graduates they studied alongside. Seven years after graduating, the majority of those interviewed had been relatively successful - and the survey data showed the considerable extent to which there had been a convergence in the outcomes of younger and older graduates as time went on. However, the interview data suggest that many of the mature graduates had to display greater determination and resilience to achieve relative labour market success to overcome employer suspicions and the problems implicit in embarking on a new career direction; many concurrently balancing other commitments and responsibilities. A key determinant of labour market success among mature graduates, as was the case for the sample as a whole, appeared to be the way in which they took advantage of opportunities, approached obstacles and handled setbacks. As in the sample as a whole, while a few appeared to dwell on the obstacles that they had faced and talked fatalistically about lack of opportunities, others responded in a proactive manner by creating and pursuing existing opportunities and manoeuvring themselves into positions to take advantage of these as they arose - and such an approach had paid off for the majority by the time they were interviewed.

\section{Summary and conclusions}

Previous research, based upon evidence from graduates who obtained their degrees before the mass expansion of the HE system, has established that mature graduates tend to experience greater difficulty than their younger peers in obtaining graduate employment, sometimes facing discrimination and, initially at least, being restricted to lower 'quality' jobs than those who took a more direct route from school to HE. We have presented evidence which reinforces this picture and shows that, 
although negative outcomes are far from inevitable, many older graduates appear to have experienced greater challenges than younger ones. The distinction that we make between 'young mature' graduates and 'older mature' graduates has enabled us to clarify the extent to which it was those who graduated over the age of 30 who were most likely to experience difficulty in accessing appropriate employment. The younger mature graduates were, in most respects, similar to the young graduates (those who pass straight through from school to university possibly with a one or two year break). In contrast, the situation for the older mature graduates was less positive. While, on average, they gained a significant pay premium for their degree, their earnings growth, particularly in the case of mature males, was lower than that of younger graduates and they were more likely to express dissatisfaction with their career development.

This could have been attributable to the type of work older mature graduates obtained, their social background and their generally lower entry qualifications. Detailed analysis shows that this was not the case. At present we are left with no better explanation than age. Perhaps the most telling evidence we have presented here comes not from the longitudinal surveys but from the detailed interviews with mature graduate respondents. For some, this had been a difficult journey - one with significant financial implications both while studying and in terms of the difficulties of regaining employment. Their accounts highlighted their relative lack of opportunities and information, and the difficulties that many had faced in drawing the attention of employers to their potential. Several accounts provided apparent evidence of ageism in employers' recruitment practices and although some of this was clearly discriminatory, it tended to be subtle, indirect and because of that, difficult to challenge.

It is timely to consider the implications of these findings in relation to changing $\mathrm{HE}$ and $\mathrm{UK}$ equal opportunities legislation revisions to take effect from October 2006 in line with the European Directive on Equal Treatment. The evidence from our research indicates clearly that mature graduates tended to take a more instrumental approach to $\mathrm{HE} \mathrm{-} \mathrm{and}$ insofar as this is the case, they are likely to assess the returns to their investment of time and resources more carefully than 'traditional' HE applicants - but they also have a greater appreciation of the wider, non-pecuniary benefits (Bynner et al., 2003) and place a lower priority on financial return than the younger graduates.

The new legislation makes age discrimination more difficult and may erode some of the differences between age groups found in earlier cohorts and, allied to employers' increasing concern with personal 
attributes and experience in response to the increased graduate labour supply, could work to the benefit of mature graduates. It is important to stress that the overwhelming majority of mature graduates, as other age groups, evaluated their $\mathrm{HE}$ experience and the opportunities that these had led to, very positively. Ongoing research on subsequent graduate cohorts will reveal whether the net effect of $\mathrm{HE}$ and employment policy changes will reinforce or put a brake on the recruitment of older $\mathrm{HE}$ entrants and their ability to realise their career aspirations.

\section{Notes}

1. Egerton's work is well recognised as a detailed study of the labour market outcomes (earnings, occupations) for mature graduates. These were defined in her study as graduates who were 26 years or older at the time they gained their first degree, for degree holders who gained their degrees between 1950 and 1992.

2. Graduate Careers Seven Years On. This research is supported by the Economic and Social Research Council (Award ref: R000239589) and the Higher Education Careers Services Unit.

3. 'Employment' consists here of employees in employment. It excludes the self-employed and a small number of jobs that fall outside the scope of the PAYE tax system.

4. Respondents were contacted first in 1998/1999 and later in 2002/2003. At each contact they provided details of all jobs held since graduating or the previous survey.

5. This estimate is made by examining the coefficients for the 'age' and 'age-squared' variables of the least squares regression model shown at the Appendix. Each additional year of age on graduation is associated (ceteris paribus) with a reduction in the real annual rate of growth of earnings of approximately 0.6 per cent. While the age-squared term moderates this effect slightly, these results imply that a 10 -year difference in age at graduation is associated with a 6 per cent per annum reduction in the rate of growth of earnings in the seven years after graduation.

\section{References}

Blasko, Z. (2002) Access to What? Analysis of Factors Determining Graduate Employability. Bristol: HEFCE.

Brennan, J. and Shah, T. (2003) Access to What? Converting Educational Opportunity into Employment Opportunity for Groups from Disadvantaged Backgrounds. London: Centre for Higher Education Research and Information (CHERI).

Bynner, J., Dolton, P., Feinstein, L., Makepeace, G., Malmberg, L. and Woods, L. (2003) Revisiting the Benefits of Higher Education. London: Bedford Group for Lifecourse and Statistical Studies, Institute of Education, University of London.

Davies, P. and Williams, J. (2001) For Me or Not for Me? Fragility and Risk in Mature Students' Decision-Making. Higher Education Quarterly, 55 (2), p. 185-203.

DfES (2003) The Future of Higher Education. Government White Paper. London: Department for Education and Skills.

Egerton, M. (2000) Pay Differentials between Early and Mature Graduate Men: the Role of State Employment. Fournal of Education and Work, 13 (3), pp. 289-306.

Egerton, M. (2001a) Mature Graduates I: Occupational Attainment and the Effects of Labour Market Duration. Oxford Review of Education, 27 (1), pp. 135-150. 
Egerton, M. (2001b) Mature Graduates II: Occupational Attainment and the Effects of Social Class. Oxford Review of Education, 27 (2), pp. 271-286.

Egerton, M. and Bynner, J. (2000) The Social Benefits of Higher Education: Insights from Longitudinal Data. London: Centre for Longitudinal Studies, Institute of Education.

Egerton, M. and Parry, G. (2001) Lifelong Debt: Rates of Return to Mature Study. Higher Education Quarterly, 55 (1), pp. 4-27.

Elias, P. and Purcell, K. (2004a) SOC (HE): A classification of occupations for studying the graduate labour market, Researching Graduate Careers Seven Years On Research Paper No. 6, Coventry: Warwick Institute for Employment Research. http://www2.warwick. ac.uk/fac/soc/ier/research/completed/7yrs2/rp6.pdf.

Elias, P. and Purcell, K. (2004) Is Mass Higher Education Working? Evidence from the Labour Market Experiences of Recent Graduates. National Institute Economic Review, No. 90, pp. 60-74. November.

Elias, P. and Rigg, M. (eds.) (1990) The Demand For Graduates. London: Policy Studies Institute.

Elias, P., McKnight, A., Pitcher, J., Purcell, K. and Simm, C. (1999) Moving On: Graduate Careers Three Years after Graduation. Manchester: CSU/DfEE.

Halford, S., Savage, M. and Witz, A. (1997) Gender, Careers and Organisations: Current Developments in Banking, Nursing and Local Government. Basingstoke: Macmillan.

Jenkins, A., Vignoles, A., Wolf, A. and Galindo-Rueda, F. (2002) The Determinants and Effects of Lifelong Learning. London: Centre for the Economics of Education.

Purcell, K., Elias, P., Davies, R. and Wilton, N. (2005) The Class of '99: a Study of the Early Labour Market Experience of Recent Graduates. London: DfES.

Purcell, K., Morley, M. and Rowley, G. (2002) Recruiting from a Wider Spectrum of Graduates. Bristol: CIHE/ESRU.

Rees, H. and Shah, A. (1995) Public-Private Sector Wage Differentials in the U.K. Manchester School, 63 (1), pp. 52-68.

\section{Appendix: Regression results for rate of growth of earnings, first main job after 1995 degree to date of survey (2002/03), graduates in full-time employment only}

\begin{tabular}{lccr}
\hline & Coefficient & Std. Error & $t$-statistic \\
\hline Constant & 13.523 & 0.495 & 27.302 \\
Subject area of study & Ref & & \\
$\quad$ Arts & 0.524 & 0.108 & 4.838 \\
Humanities & 0.308 & 0.136 & 2.257 \\
Languages & 3.342 & 0.138 & 24.298 \\
Law & 1.523 & 0.095 & 16.047 \\
Social sciences & 3.264 & 0.115 & 28.308 \\
Maths and computing & -0.069 & 0.098 & -0.707 \\
Natural science & 0.897 & 0.120 & 7.450 \\
Medicine and related & 0.750 & 0.102 & 7.346 \\
Engineering & 2.870 & 0.099 & 29.083 \\
Business studies & 0.025 & 0.114 & 0.218 \\
Education & 1.504 & 0.117 & 12.882 \\
Other vocational & 2.188 & 0.177 & 12.391 \\
Interdisciplinary & & &
\end{tabular}


Appendix: Continued

\begin{tabular}{|c|c|c|c|}
\hline & Coefficient & Std. Error & $t$-statistic \\
\hline \multicolumn{4}{|c|}{ Type of institution attended } \\
\hline Old university & Ref & & \\
\hline 1960s university & 0.116 & 0.082 & 1.420 \\
\hline 1992 university & 0.790 & 0.061 & 13.054 \\
\hline HE college & -0.322 & 0.100 & -3.211 \\
\hline \multicolumn{4}{|l|}{ Entry qualifications } \\
\hline A-levels, $24+$ points & Ref & & \\
\hline A-levels, $16-23$ points & -0.496 & 0.070 & -7.105 \\
\hline A-levels, $<16$ points & -0.595 & 0.081 & -7.315 \\
\hline Scottish highers & -0.924 & 0.090 & -10.224 \\
\hline Access quals & -1.695 & 0.145 & -11.728 \\
\hline Foundation course & 0.392 & 0.218 & 1.799 \\
\hline $\mathrm{HND} / \mathrm{HNC}$ & -1.010 & 0.101 & -10.044 \\
\hline GNVQ & 1.253 & 0.261 & 4.793 \\
\hline Baccalaureate & 0.866 & 0.417 & 2.076 \\
\hline O levels & -1.403 & 0.236 & -5.941 \\
\hline BTEC, ONC/OND & -1.036 & 0.143 & -7.240 \\
\hline First degree & -2.484 & 0.223 & -11.118 \\
\hline Postgrad qual & -0.695 & 0.464 & -1.497 \\
\hline Other & -2.515 & 0.132 & -19.122 \\
\hline \multicolumn{4}{|l|}{ Class of degree awarded } \\
\hline First & 1.142 & 0.129 & 8.865 \\
\hline Upper second & 0.899 & 0.113 & 7.981 \\
\hline Lower second & 1.293 & 0.115 & 11.288 \\
\hline Third & Ref. & & \\
\hline Unclassified & 0.706 & 0.261 & 2.707 \\
\hline Ordinary/pass & 0.869 & 0.148 & 5.874 \\
\hline Diploma & -1.484 & 0.862 & -1.722 \\
\hline Postgrad qual & 2.190 & 0.446 & 4.913 \\
\hline
\end{tabular}

Parental social background

Professional

Managerial/technical

Ref.

Skilled non-manual

0.119

0.064

1.865

$-0.732$

0.089

$-8.195$

Skilled manual

$-0.442$

0.074

$-5.989$

Partly skilled

0.108

$-8.341$

Unskilled

$-0.903$

0.193

$-8.650$

Armed forces

$-1.667$

0.208

8.961

0.472

0.264

1.789

No information

Type of occupation held

Traditional graduate job

0.364

0.083

4.380

Ref.

Modern graduate job

$\begin{array}{rrr}1.009 & 0.065 & 15.474 \\ 0.774 & 0.066 & 11.709 \\ 0.691 & 0.090 & 7.648 \\ -1.843 & 0.086 & -21.329\end{array}$


Appendix: Continued

\begin{tabular}{lrlr}
\hline & Coefficient & Std. Error & $t$-statistic \\
\hline Male & 1.154 & 0.049 & 23.778 \\
Age at graduation & -0.615 & 0.033 & -18.880 \\
Age squared & 0.007 & 0.000 & 14.069 \\
$R^{2}$ & 0.151 & & \\
Number of observations & 2,900 & & \\
\hline
\end{tabular}

Dependent variable: annual rate of growth of real annual gross earnings, from first main job after graduation in 1995 to date of survey (2002/2003. For both male and female graduates, the distribution of growth rates across the full sample is approximately normal, with a modal value in the range $7-9 \%$ per annum. Five per cent of respondents experienced a real decline in their earnings over the seven years since graduating and five per cent experienced growth rates of over 20 per cent per annum.

With the exception of the age variable and the dependent variable, all other variables used in this least squares regression are binary $(0,1)$ variables. The coefficients on these variables can be interpreted as the effect (ceteris paribus) on annual real earnings growth of the variable associated with the coefficient, relative to the reference category. For example, having studied at a 1992 university is associated with an increased annual rate of growth of real earnings on $0.8 \%$ relative to having studied at an old university.) 